\title{
High-energy physics faces fight for survival
}

Washington. High-energy physics facilities in the United States face deep cuts in their operating budgets for the third year running, according to a number of laboratory chiefs who addressed the Department of Energy's High Energy Physics Advisory Panel (HEPAP) in Washington last week.

Members of the panel, which advises the government on its expenditure on the field, point out that a continuation of present reach zero by the year 2005 . "What I'm worried about in this field is its survival," said Donald Hartill of Cornell University in New York state.

Fellow panellist Pierre Ramond of the University of Florida applied some dry humour to the situation: "In this society, if something is not healthy, you shoot it". HEPAP has heard this sort of doom-mongering before (Nature 362, 581; 1993); but this time, in the wake of last October's demise of the Superconducting Super Collider (SSC), the physicists may not be crying wolf.

Certainly any hopes that established highenergy physics facilities would benefit from the collapse of the mammoth Texan project have already evaporated. The Department of Energy is to spend $\$ 640$ million this year on closing the SSC, and $\$ 180$ million next year; but as the albatross falls away, the budget request for the rest of the programme remains stagnant at $\$ 620$ million.

Furthermore, because of new construction projects at Fermilab, Illinois, and the Stanford Linear Accelerator Center (SLAC) in California, operating budgets will dip by four per cent, for the third year running.

Fermilab, SLAC and the third main facility, at Brookhaven, New York, are each planning staff cuts to prevent further reductions in the proportion of the year for which they can operate their accelerators. Cashstrapped high-energy physicists are also worried that they will get saddled with runtrends would see these operating budgets

The disappearance of $\$ 44,000$ worth of personal computers from the site of the Superconducting Super Collider (SSC) at Waxahachie, Texas (right), in January has prompted a harsh security clampdown, according to SSC director John Peoples. At the same time, tensions between the Department of Energy (DoE) and the State of Texas are souring the atmosphere under which the project is being wound down.

The Federal Bureau of Investigation is looking into the computer loss, and the energy department, concerned about attracting the attention of congressmen such as John Dingell (Democrat, Michigan), has quadrupled the security budget on the site to $\$ 265,000$ a month. Peoples, who remains director of Fermilab but is spending three days a week at Waxahachie, told a meeting last week of the DoE's High Energy Physics Advisory Panel that the clampdown makes a difficult job harder.

Relations between University Research Associates - the SSC contractor - the DoE and the state of Texas are strained. But Peoples appears determined to remain cheerful in the face of adversity. "People are working very hard. There are still some

ning yet another facility in Texas when the energy department and the state government strike a deal on what to do with the SSC site (see box). "The SSC is worse than irrelevant," says panel member Stewart Smith of Princeton University, New Jersey. "It's becoming a tax on the whole programme."

But these straitened circumstances also raise questions about the efficacy of HEPAP, an open forum born in the heady 1960 s but perhaps ill-suited to help manage a programme in contraction. Faced with competing demands on diminishing resources, HEPAP appears unable to set clear priorities, because, if it does, it risks losing those

\section{Academic aid sets out for Yugoslavia}

Paris. A convoy of lorries will set out from Strasbourg in France next month to deliver 30 tonnes of books and academic journals to the universities of Zagreb and Belgrade in the former Yugoslavia.

The convoy, and an air shipment to Sarajevo, where the university library has been destroyed, is one of several projects organized by academics and students at universities in Strasbourg. The group, "Students and teachers for Sarajevo", chose Sarajevo as a focus for attention, but is working for peace throughout former Yugoslavia.

In particular, the group has invited 30 students from Bosnia-Herzegovina, Croatia, Serbia, Slovenia and Macedonia to take part in a public conference in Strasbourg from 2 to 6 May. The conference, timed to coincide with a sitting of the European Parliament, will consider how universities can help in rebuilding peace, as well as wider issues raised by the Yugoslav war.

"We are trying to re-establish the bridges that have been broken between them", says Ronald Hancock, a researcher at the Institute of Biological Chemistry in Strasbourg, who is on sabbatical leave from Canada. For further information, contact "EtudiantsEnseignants pour Sarajevo", 4 rue Thiergarten, 67000 Strasbourg, France (Tel.: 33.88.75.56.58, Fax: 33.88.37.97.25).

Declan Butler

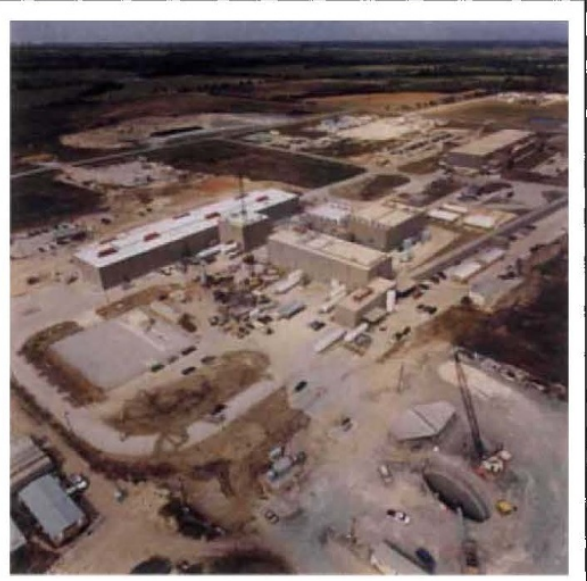

old wounds but we're doing our best," he says.

The main problem at SSC is how to retain people to carry out key tasks. Staff numbers at the laboratory have already fallen from 2,000 last September to $\mathbf{8 5 0}$, and will wind down to zero by September 1995. But the management issues which Peoples is responsible for will, he hopes, be resolved long before then. "I could be out of here by this summer," he says.

projects placed lower on the priority list, as well as the money that comes with them.

At the moment, a HEPAP sub-panel chaired by Sidney Drell of SLAC is preparing a report on how the programme should proceed post-SSC, and in particular on prospects for collaboration with European highenergy physics (Nature 367, 397; 1994). After that, HEPAP's chairman, Stan Wojcicki of Stanford University, would like another sub-panel to meet in private and set priorities for the rest of the programme. But several panel members warned that such a process would be fraught with danger.

In the meantime, Wojcicki is planning to write yet another letter to Hazel O'Leary, the Secretary of Energy, complaining about the budget allocation. But he is painfully aware of its likely ineffectiveness. "I'd like to do something more dramatic or effective, but I don't know what," he says.

"HEPAP is in the mood that the sun is setting," observes Bernard Hildebrand, a former head of physics research in the energy department. He suggests that the community should organize a small group of its best people to go out and sell what they are doing to key officials in Washington.

These would include officials in the energy department, the National Science Foundation, the White House science office and both houses of Congress. But the trouble is that Washington knows their faces; and the last time they came to lunch, they were selling an \$11-billion project that turned out to be a white elephant. Colin Macilwain 